\title{
Vaticinating Multiphase Flow Chattels of Electrical Submersible Pumps Operating Points: an Impregnable Aberrant to Production Optimization in Low GOR Reservoirs
}

\author{
Anthony. J. Ilozobhie \\ Department of Physics \\ University of Calabar, Unical \\ Calabar, Nigeria.
}

\author{
Daniel. I. Egu \\ Petroleum Department \\ Madonna University \\ Enugu, Nigeria
}

\author{
Joel. S. Udoh \\ Physics Department \\ University of Calabar, Unical \\ Calabar, Nigeria
}

\begin{abstract}
Pressure Volume and Temperature (PVT) Data, reservoir and production data and Electrical Submersible Pumps (ESP) Equipment Data were used with PROSPER software in a sensitivity analysis for a severely depleted Gas to Oil Ratio (GOR) well in an offshore XM-Oil Field of the Niger Delta, Nigeria. The objectives were to run comprehensive and detailed sensitivity analysis of ESP model using IPM-PROSPER suite for different flow conditions from the ESP operating point locations in casing slugs, tubing slugs, tie-back intermittent and riser intermittent model predictions within the vicinity of the superficial liquid and gas velocity domains in order to predict pump discharge pressures and rates, the actual head, pump frequency, pump intake pressures, fluid rates and temperatures. The result shows that the centrilift pump discharge rate was $12,755.3 \mathrm{RB} /$ day. The actual head required is $6712.02 \mathrm{ft}$ and the best pump operating frequency is $60 \mathrm{~Hz}$. The predicted slip liquid velocities is from a minimum of $1.181 \mathrm{ft} / \mathrm{sec}$ for casing slugs, $1.874 \mathrm{ft} / \mathrm{sec}$ for riser-intermittent, $3.158 \mathrm{ft} / \mathrm{sec}$ for tubing slugs and a maximum of $3.349 \mathrm{ft} / \mathrm{sec}$ for tie-back intermittent flow. Furthermore, a mathematical model was generated gave as $V_{S L}=-0.863 x^{2}+4.542 x-2.492$ for the slip liquid velocity with $\mathbf{R}^{2}=0.999$. The model predicted the slip gas velocities from a minimum of $4.470 \mathrm{ft} / \mathrm{sec}$ for riser intermittent, $17.964 \mathrm{ft} / \mathrm{sec}$ for casing slugs, $23.640 \mathrm{ft} / \mathrm{sec}$ for tie back intermittent to a maximum of $42.343 \mathrm{ft} / \mathrm{sec}$ for tubing slug flows and the physicomathematical model generated $V_{S G}=7.102 x^{3}-64.15 x^{2}+167.1 x$ - 92.11 with $\mathbf{R}^{2}=1$. Upon installation of the ESP, oil production was improved while critical parameters such as pump speed or electric - power frequency $(\mathrm{Hz})$ are set to optimize pump performance while monitoring multiphase problems which reduces the operating efficiency or damages the pumps technically designed for liquids and not gases or solids.
\end{abstract}

Keywords: Pump intake, pump discharge, modeling, Gas oil ratio, sensitivity

\section{INTRODUCTION}

The XM-Field was discovered in 1982 and put on stream in 1988 with 6 production wells with initial low GOR but later depleted because of the inherent aquifer energy which is why water influx replacement is a required candidate for its fast depleting energy. With a production rate of over 40,000 bbl/day per well, electrical submersible pump is the first choice candidate in a field inherent with multiphase flow issues particularly two general topologies identified beyond the depth of 6,500ft namely the dispersed flows consisting of finite particles, drops or bubbles distributed within a continous phase and the separated flows consisting of two or more continuous streams of fluids separated by interfaces. The prominent three phase flow identified was the gas-liquid-liquid flows which abound within the proximity of the predicted ESP operating points. Production enhancement of oil from this severely depleted reservoir could be very problematic when devoid of adequate technical ideas of managing multiphase flow challenges aimed at not just solving the problem but offering managerial/monitoring solutions [6] [9] [10] and [1].

Choice of decision of ESP artificial lift technique is most times very difficult when technical, experience and economics are not considered. Electrical submersible pumps on the other hand may pose a major challenge when its performance are not well modeled with fluid phase issues as this could affect the operational efficiency before, during and after installation [2], [3], [5] [7] and [8].

The aim and objectives are; to run sensitivity analysis of ESP model for different flow conditions from the ESP operating points in casing slugs, tubing slugs, tie-back intermittent and riser intermittent model predictions within the vicinity of the superficial liquid and gas velocity domains to predict pump discharge pressures and rates and to predict the actual head, pump frequency, pump intake pressures, rates and temperatures [4].

\section{MATERIALS AND METHODOLOGY}

Materials used are Petroleum Experts IPM Prosper (Software), PVT Data, reservoir and production data and ESP Equipment Data. A well model was built for a natural flowing oil using PROSPER updated with PVT calibration 
and then matched against actual well test data. The well has been in production since 1988, reservoir pressure had declined, water cut has increased and well deliverability has reduced. To improve well productivity the well has to be converted to an Electrical Submersible Pump - lifted well. The choice of selection of the electrical submersible pump (ESP) is purely based on strict technical and economic specification. The pump type used is the centrilift K140: 538 inches with a liquid operating rate ranging from 11,500 $\mathrm{RB} /$ day to a maximum of $18,400 \mathrm{RB} /$ day. The in-built motor capacity is the centrilift 562: 450 HP: 2460: at 105 amps. The cable capacity is the number 1 copper 0.26 (volts/1,000ft); at 115 amps maximum capacity (Fig. 1).

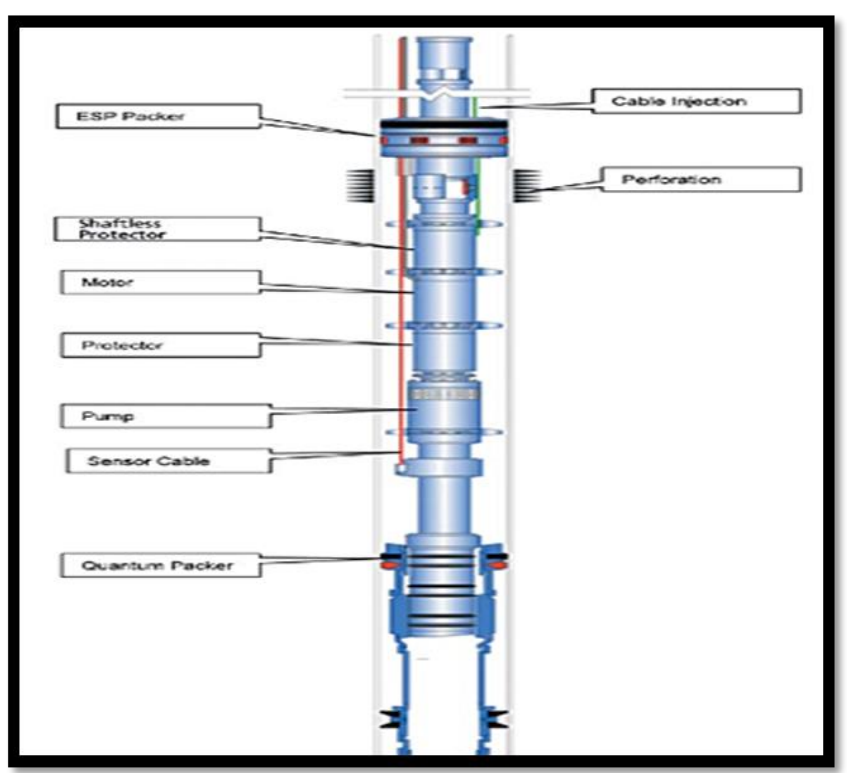

Fig. 1: Sketch showing the schematic for an Electrical Submersible Pump

\section{RESULTS AND DISCUSSIONS}

Results obtained were for the IPR Plot (Darcy), Gas Separation Plot, Pump Performance Curve, Pump Discharge Pressure against Vertical Lift Performance (PDP vs. VLP), Sensitivity Plot and ESP solution Pump Plot for the multiphase modeling.

\section{Results of IPR (Darcy)}

Results of the Inflow Performance Relationship curve of the existing production data shows that between a pressure of 4000psig and 1300psig at corresponding flow rates of OSTB/day and 19863.5STB/day, this corresponds to the straight line region indicating the single phase oil zone and also between a pressure of 1300psig and 1.108psig at corresponding flow rates of $19863.5 \mathrm{STB} /$ day and 26044.6STB/day and this corresponds to the curved region indicating a multi - phase oil and gas zone (Fig. 2). Results also show that the Absolute Open Flow (AOF) was predicted as 26044.6STB/day while the Formation Productivity Index and the Skin Factor obtained are 10.06STB/day/psi and 2.0 respectively (Fig. 2).

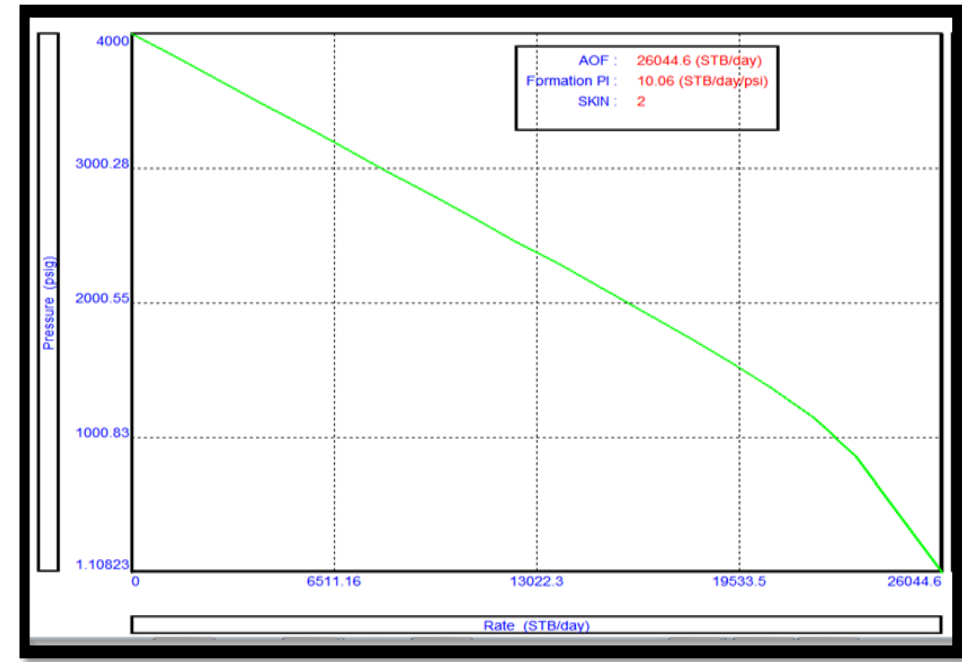

Fig. 2: Result of IPR Plot Darcy

\section{Results of gas separation}

Results of the Gas separation sensitivity plot predicts the test point at an intake pressure of 2000psig and a gas liquid ratio of approximately 0v/v and the Dunbar factor (red curve) at an intake pressure of 1500psig and a gas liquid ratio of $2.4 \mathrm{v} / \mathrm{v}$. Due to the test point pressure being above the red curve (Dunbar factor) this thereby indicates that down-hole separation is not needed (Fig. 3).

\section{Results of pump performance curve}

Results of the pump performance curve calculates the minimum operating range of the pump which shows that at a maximum frequency of 70 hertz the pump will have an operating rate of $8000 \mathrm{RB} /$ day at a depth of 6800 feet and at a minimum frequency of 40 hertz the pump will have an operating rate of $4550 \mathrm{RB} /$ day at a depth of 2200 feet and also calculates the maximum operating range of the pump which shows that a maximum frequency of 70hertz the pump will have an operating rate of $17800 \mathrm{RB} /$ day at a depth of 3300 feet and at a minimum frequency of 40 hertz the pump will have an operating rate of $10000 \mathrm{RB} /$ day at a depth of 1000 feet. It then calculates the best efficiency line of the pump which shows that at a maximum frequency of 70hertz the pump will have an operating rate of $13500 \mathrm{RB} /$ day at a depth of 5470 feet and at a minimum frequency of 40 hertz the pump will have an operating rate of $8000 \mathrm{RB} /$ day at a depth of 1800 feet (Fig. 4).

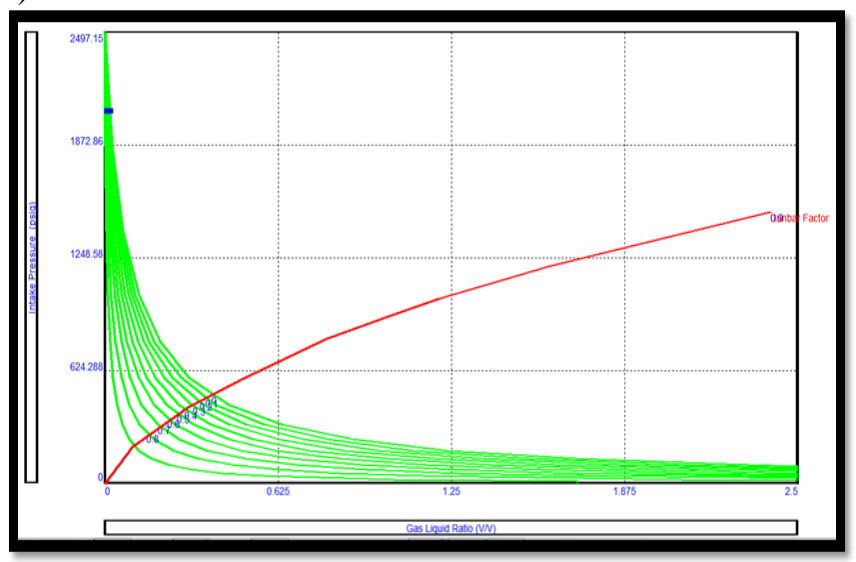

Fig. 3: Result of Gas Separation Sensitivity Plot 


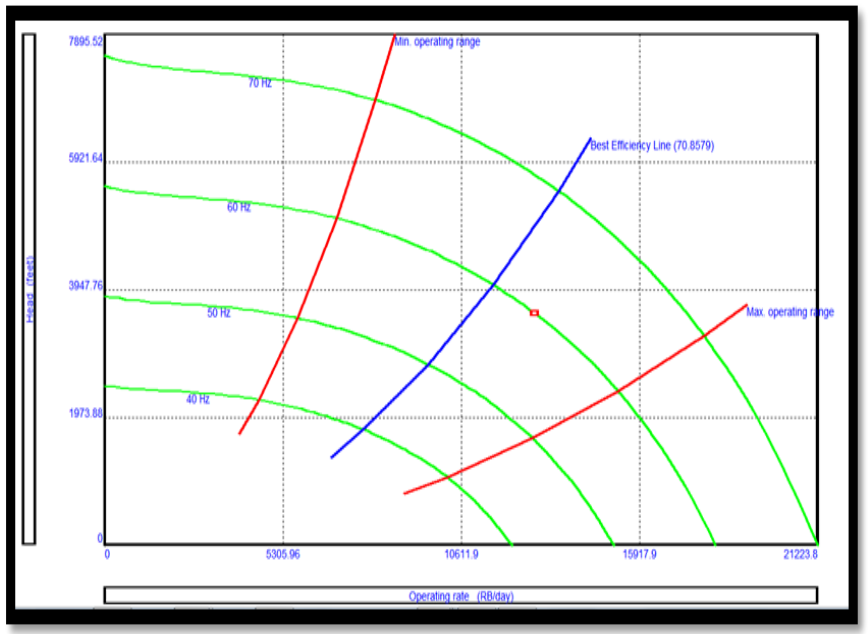

Fig. 4: Result of Pump Performance Curve

\section{Results of PDP and VLP pressure plot}

Results of the Pump Discharge Pressure against Vertical Lift Performance shows that the Pressure plot combines Inflow performance relation curve, vertical lift performance curve, pump intake pressure curve and the pump discharge pressure curve. The intersection between the VLP curve and the PDP curve is the solution rate which shows that at a minimum frequency of 40hertz the pump will be operating at a pressure of 3335 psig and have a liquid rate of 7500 stb/day and at a frequency of 45 hertz the pump will be operating at a pressure of 3378psig and have a liquid rate of 8500 stb/day and at a frequency of 50hertz the pump will be operating at a pressure of 3400psig and have a liquid rate of 9700 stb/day and at a frequency of 55hertz the pump will be operating at a pressure of 3500psig and have a liquid rate of $10800 \mathrm{stb} /$ day and at a frequency of 60hertz the pump will be operating at a pressure of 3550psig and have a liquid rate of 12000 stb/day and at a frequency of 65 hertz the pump will be operating at a pressure of 3660psig and have a liquid rate of 13200stb/day and also at a maximum frequency of 70hertz the pump will be operating at a pressure of 3720 psig and have a liquid rate of 14400stb/day (Fig. 5).

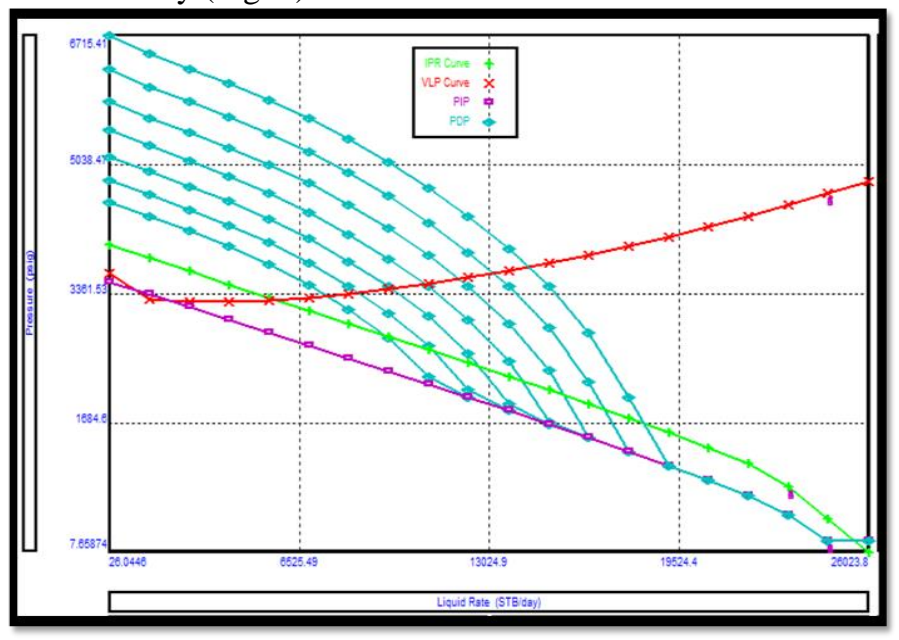

Fig. 5: Result of PDP vs. VLP Pressure Plot
Results of the sensitivity analysis

Results of gas separation sensitivity showed that of the 10 models used, the predicted operating pump intake pressure is 2087.32psig; the pump intake temperature is $199.168^{\circ} \mathrm{F}$ and pump intake rate of $12,936.5 \mathrm{RB} /$ day. Free GOR entering the pump is 67.7666scf/STB and pump discharge pressure is 3225.07 psig. The pump discharge rate is given as $12,755.3$ $\mathrm{RB} /$ day. The actual head required is $2712.02 \mathrm{ft}$ and pump frequency is $60 \mathrm{~Hz}$ (Fig. 6).

\section{Result of the ESP solution pump}

Results of the ESP solution pump plot predicts that at a minimum frequency of 40hertz the pump will have a depth of $1700 \mathrm{ft}$ and an operating rate of $7950 \mathrm{RB} /$ day and at a frequency of 45 hertz the pump will have a depth of $2150 \mathrm{ft}$ and an operating rate of $9100 \mathrm{RB} /$ day and at a frequency of 50 hertz the pump will have a depth of $2600 \mathrm{ft}$ and an operating rate of $10300 \mathrm{RB} /$ day and at a frequency of 55hertz the pump will have a depth of $3050 \mathrm{ft}$ and an operating rate of $11600 \mathrm{RB} /$ day and at a frequency of 60 hertz the pump will have a depth of $3550 \mathrm{ft}$ and an operating rate of $12650 \mathrm{RB} /$ day and also at a frequency of 65hertz the pump will have a depth of $4100 \mathrm{ft}$ and an operating rate of $14100 \mathrm{RB} /$ day and lastly at a maximum frequency of 70 hertz the pump will have a depth of $4680 \mathrm{ft}$ and an operating rate of $15400 \mathrm{RB} / \mathrm{day}$. This shows that the ESP will be operating within a safe operating range (i.e. between its minimum and maximum operating range) (Fig. 7).

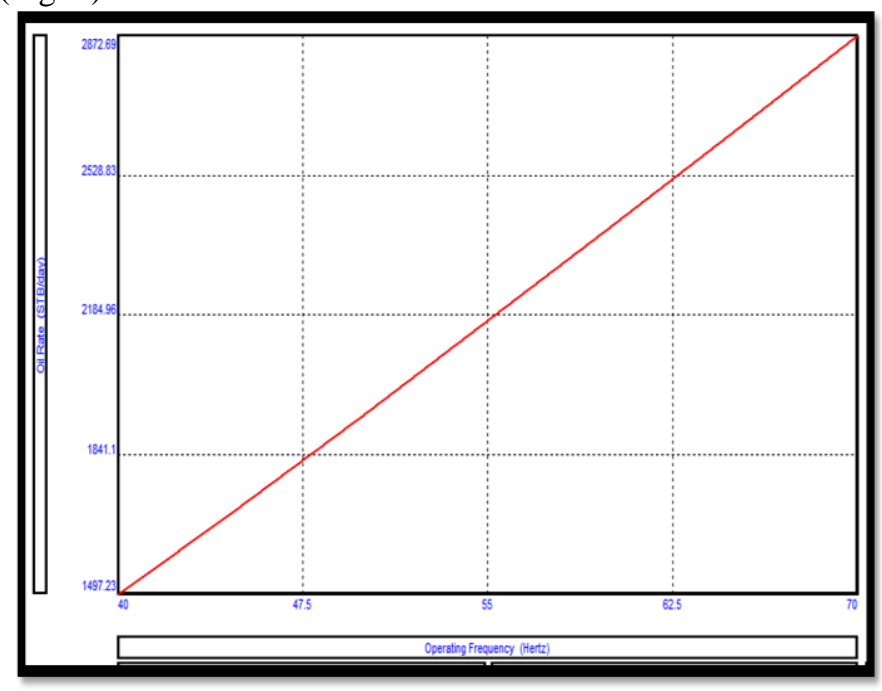

Fig. 6: Sensitivity Plot of Oil rate vs. Pump operating frequency 


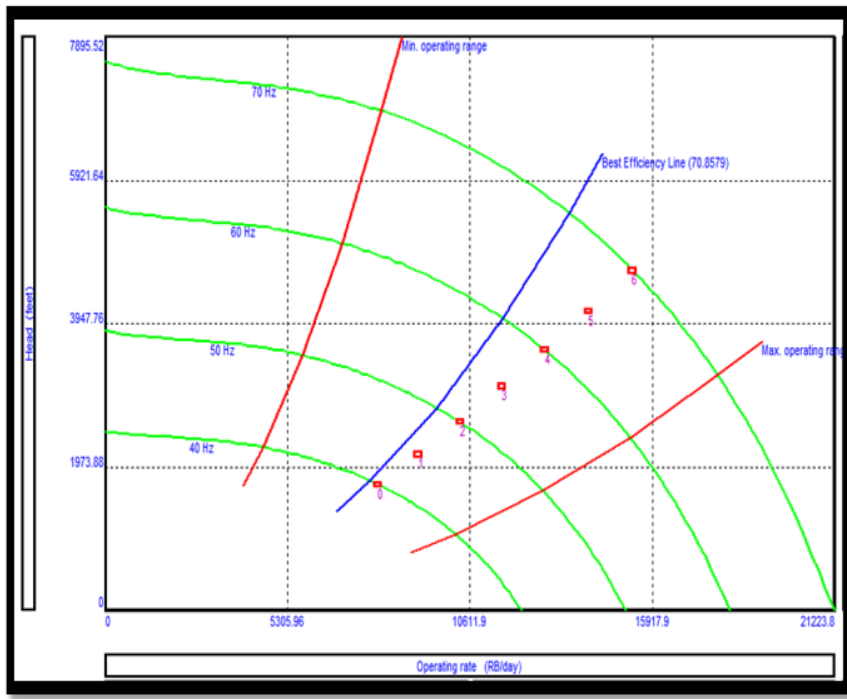

Fig. 7: Result of ESP Solution Plot

Result of multiphase flow regime modeling for casing slug Result of casing slug modeling shows that the ESP operating point was located at approximately a superficial liquid velocity of $0.2 \mathrm{ft} / \mathrm{sec}$ and superficial gas velocity of $1.3 \mathrm{ft} / \mathrm{sec}$. This is far away from the annular flow (green), dispersed bubble (blue) and the bubble flow (red) as shown in Fig. 8.

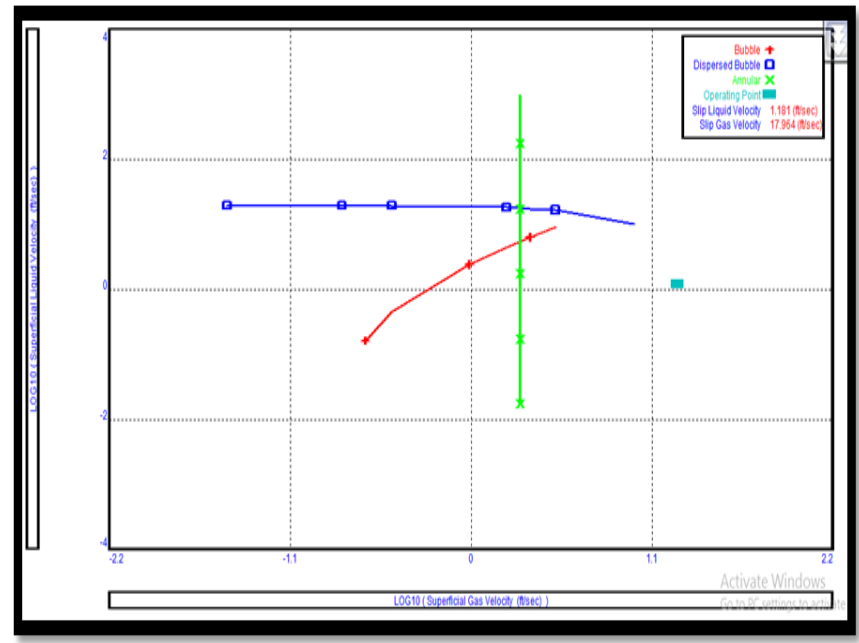

Fig. 8: A graph of Casing slug which indicate the operating point against the superficial gas and liquid velocity.

Result of multiphase flow regime modeling for Tubing slug Results was predicted to be slightly better than casing slug modeling because the predicted operating point was further away from the bubble, dispersed bubble and annular flow regimes. Operating point was actually located at a superficial liquid velocity of $0.35 \mathrm{ft} / \mathrm{sec}$ at a corresponding gas velocity of 1.16ft/sec as shown in Fig. 9.

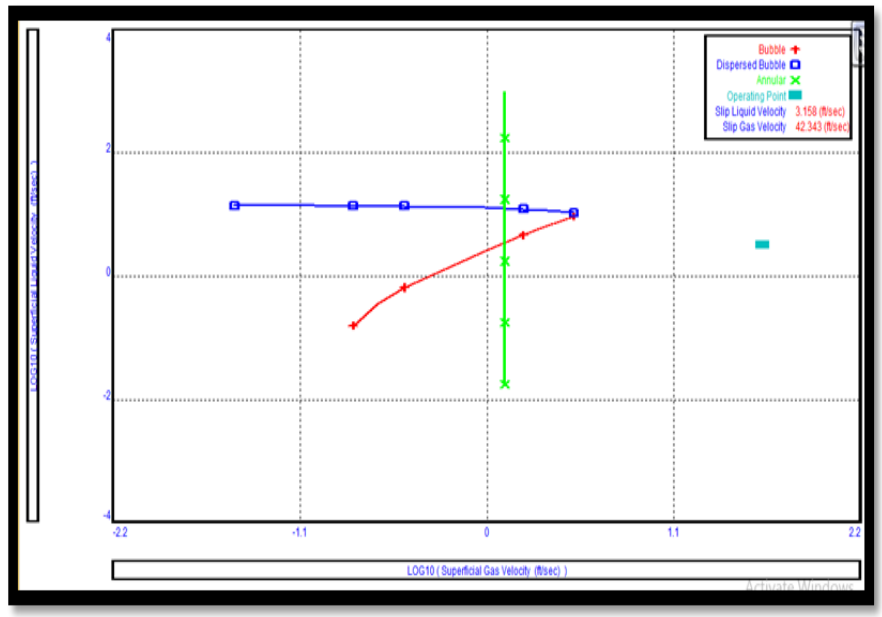

Fig. 9: A graph of Tubing slug which indicate the operating point against the superficial gas and liquid velocity.

Result of multiphase flow regime modeling for Tie-back intermittent

The tie back liner is run from a liner hanger back to the well head after the initial liner and hanger system have been installed and cemented and provides pressure support during flow test periods and not cemented in place. Results of the tie-back intermittent shows that the operating point located at a superficial liquid velocity of $0.4 \mathrm{ft} / \mathrm{sec}$ and at a superficial gas velocity of $1.5 \mathrm{ft} / \mathrm{sec}$ is too close to the slug annular flow (yellow) while the stratified-slug/annular flow regime, severe slugging line and slug dispersed bubble are close to the operating point. This is not a good candidate for the ESP design installation (Fig. 10).

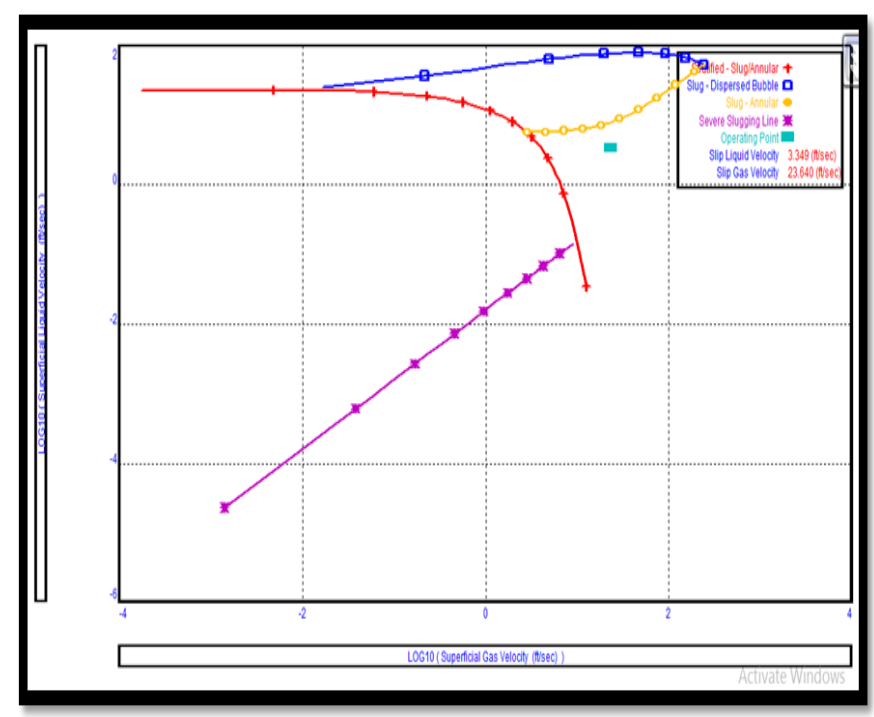

Fig. 10: A graph of Tie back - intermittent which indicate the operating point against the superficial gas and liquid velocity.

Result of multiphase flow regime modeling for Riser Intermittent

The riser is the pipe that connects an offshore floating production structure or a drilling rig to a sub-sea system either for production (for storage, transportation and export), drilling, injection, completion and work-over operations. 
Result of exact location of the operating point was located at superficial liquid velocity of $0.3 \mathrm{ft} / \mathrm{sec}$ and superficial gas velocity of $0.7 \mathrm{ft} / \mathrm{sec}$. The nearest flow regime is bubble followed by dispersed bubble and annular flow regime (Fig. 11).

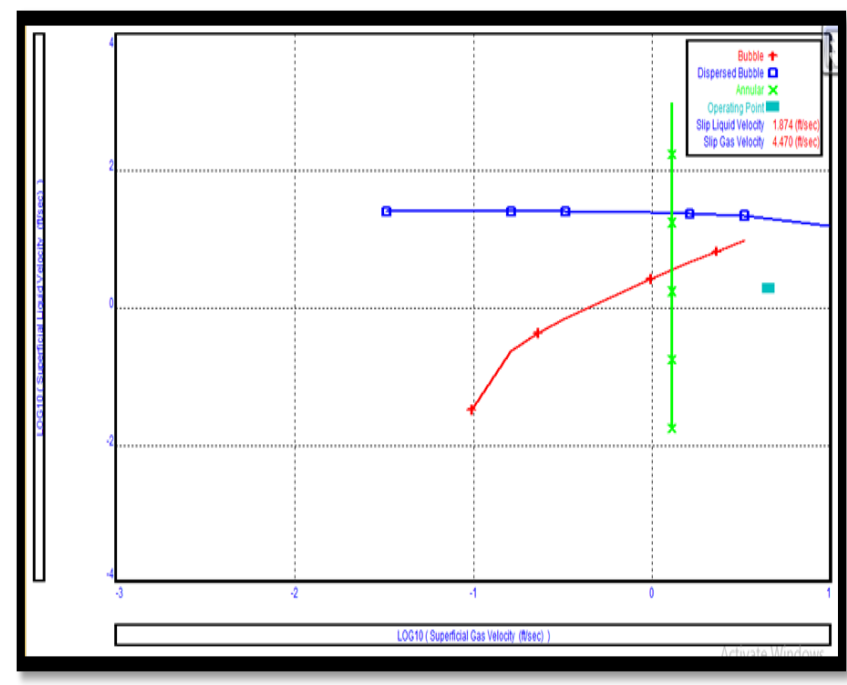

Fig. 11: A graph of Riser intermittent which indicate the operating point against the superficial gas and liquid velocity.

\section{MAJOR RESULTS}

The predicted slip liquid velocities is from a minimum of $1.181 \mathrm{ft} / \mathrm{sec}$ for casing slugs, $1.874 \mathrm{ft} / \mathrm{sec}$ for riser-intermittent, $3.158 \mathrm{ft} / \mathrm{sec}$ for tubing slugs and a maximum of $3.349 \mathrm{ft} / \mathrm{sec}$ for tie-back intermittent flow while its physic-mathematical model gave $\mathrm{V}_{\mathrm{SL}}=-0.863 \mathrm{x}^{2}+4.542 \mathrm{x}-2.492$ with $\mathrm{R}^{2}=$ 0.999 . The predicted slip gas velocities is from a minimum of $4.470 \mathrm{ft} / \mathrm{sec}$ for riser intermittent, $17.964 \mathrm{ft} / \mathrm{sec}$ for casing slugs, $23.640 \mathrm{ft} / \mathrm{sec}$ for tie back intermittent to a maximum of $42.343 \mathrm{ft} / \mathrm{sec}$ for tubing slug flows and its physicmathematical model gave $V_{S G}=7.102 x^{3}-64.15 x^{2}+167.1 x-$ 92.11 with $\mathrm{R}^{2}=1$ (Table 1 and figure 12). The ESP solution plot portrayed all the operating points lying close to the middle placed best efficiency curve line indicating the higher the ESP operating efficiency, the higher the liquid rates. Results of casing slugs effects on the ESP operating points indicates that by increasing the superficial gas velocity and reducing the superficial liquid velocities of the dispersed bubble phase model, this would have adverse operating effects on the ESP while the bubble and annular flows have literally no effects on pump.

However, results of tubing slug model effects indicates that the ESP operating point was located farther away than its location in the casing slug model showing an improvement in the modeling but if on the other hand there was a simultaneous slight increase in the superficial liquid and gas velocities, the pump would definitely be affected.

Results of the tie-back intermittent models showed the presence of 4 multiphase flows which includes stratified slug annular, slug-dispersed bubble, severe slug line and slug annular. The predicted slip liquid velocity is $3.349 \mathrm{ft} / \mathrm{sec}$ and the slip gas velocity is $23.640 \mathrm{ft} / \mathrm{sec}$. interestingly, it was identified that a reduction in the superficial liquid velocity of the slug annular flow will affect the pump. Caution should however be applied in managing the scenario as any disruption in the phases may affect the ESP operating performance efficiency capacity. Results of the riser intermittent flow indicates a three phase scenario with serious issues if reductions in dispersed bubble and bubbles exist for the superficial liquid velocities with increase superficial gas velocities.

\section{TABLE 1: PREDICTED MULTIPHASE FLUIDS AND} SUPERFICIAL VELOCITIES

\begin{tabular}{|l|c|c|c|c|}
\hline $\begin{array}{l}\text { Multiphase } \\
\text { parameters }\end{array}$ & Casing slugs & $\begin{array}{l}\text { Tubing } \\
\text { slugs }\end{array}$ & $\begin{array}{l}\text { Tie-back } \\
\text { intermittent }\end{array}$ & $\begin{array}{l}\text { Riser } \\
\text { intermittent }\end{array}$ \\
\hline $\begin{array}{l}\text { Slip liquid } \\
\text { velocity } \\
\text { (ft/sec) }\end{array}$ & 1.181 & 3.158 & 3.349 & 1.874 \\
\hline $\begin{array}{l}\text { Slip gas } \\
\text { velocity } \\
\text { (ft/sec) }\end{array}$ & 17.964 & 42.343 & 23.640 & 4.470 \\
\hline $\begin{array}{l}\text { Multiphase } \\
\text { fluids }\end{array}$ & $\begin{array}{l}\text { Bubble, } \\
\text { Dispersed } \\
\text { bubble and } \\
\text { annular }\end{array}$ & $\begin{array}{l}\text { Bubble, } \\
\text { Dispersed } \\
\text { bubble and } \\
\text { annular }\end{array}$ & $\begin{array}{l}\text { Stratified- } \\
\text { slug annular, } \\
\text { slug- } \\
\text { dispersed } \\
\text { bubble, slug- } \\
\text { annular and } \\
\text { severe } \\
\text { slugging line }\end{array}$ & $\begin{array}{l}\text { Bubble, } \\
\text { Dispersed } \\
\text { bubble and } \\
\text { annular }\end{array}$ \\
\hline
\end{tabular}

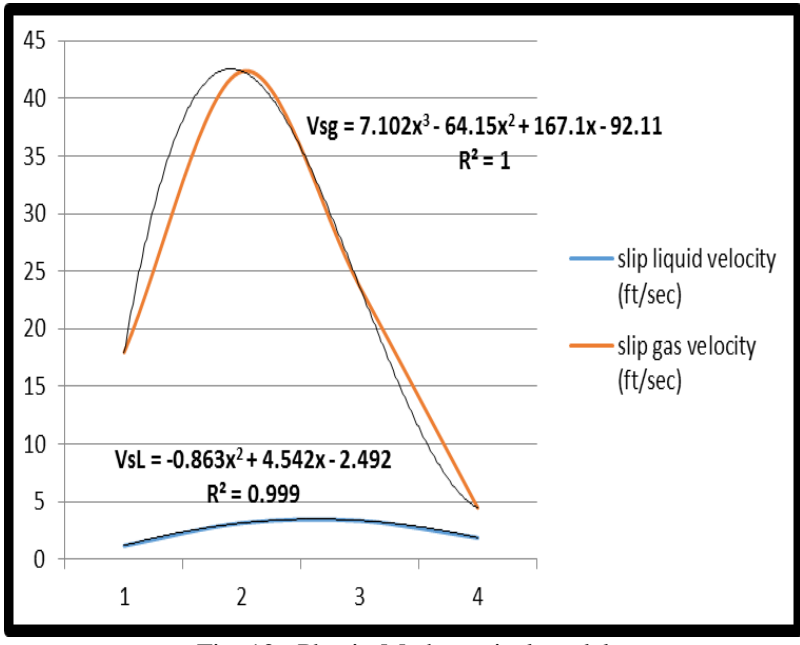

Fig. 12: Physic-Mathematical model

\section{CONCLUSION}

A careful technical juxta-positioning of all the sensitized models of casing slugs, tubing slugs, tie-back intermittent and Riser intermittent results showed the advantage and preferred option of the tubing slug model over others because the predicted operating ESP points is located away from the complex multiphase fluids. This is followed by the casing slug, riser intermittent and the tie-back intermittent as the most sensitive.

This research can greatly improve the way we model ESP in the vicinity of complex fluids that can trigger multiphase flows. The technical thinking should be concise premodeling, history matching and post-modeling (or ESP production monitoring to curtail flow challenges). The optimization methods investigated here are effective for problems of varying complexities and sizes. The methods can be used for both short-term production optimizations and 
long-term reservoir development studies. Upon installation of the ESP, oil production was improved while critical parameters such as pump speed or electric - power frequency $(\mathrm{Hz})$ are set to optimize pump performance while monitoring multiphase problems which reduces the operating efficiency or damages the pumps technically designed for liquids and not gases or solids.

$\begin{array}{ll}\text { Acronyms } & \text { NOMENCLATURE } \\ \text { DV }= & \text { decision variable } \\ \text { GOR }= & \text { gas oil ratio } \\ \text { IP }= & \text { integer programming } \\ \text { LP }= & \text { linear programming } \\ \text { LIP }= & \text { linear integer programming } \\ \text { MIP }= & \text { mixed integer programming } \\ \text { PWM }= & \text { predictive well management } \\ \text { WPOM }= & \text { western production optimization model } \\ \text { WI }= & \text { well index }\end{array}$

\section{REFERENCES}

[1] Aronofsky, J.S. Optimization Methods In Oil and Gas Development, SPE, conference paper $1983 ; 12295$.

[2] Aronofsky, J.S, Lee, A.S, The Use Of Linear Programming Model For Scheduling Crude Oil Production, 1988, Trans., Aime 213, 5154.

[3] Barnes, D. A., Humphrey, K., and Muellenberg, L., A Production Optimization System For Western Prudhoe Bay Field, Alaska, 1990, Paper Spe 20653 Presented At The 65th Annual Technical Conference And Exhibition Of The Society Of Petroleum Engineers Held In New Orleans, La, September 23-26.

[4] Bertsimas, D., and Tsitsiklis, J., Introduction To Linear Optimization, 1997, Athena Scientific, Belmont, Massachusetts.

[5] Dutta-Roy, K., and Kattapuram, J., A New Approach To Gas-Lift Allocation Optimization, 1997, SPE paper 38333 Presented At The 1997 Spe Western Regional Meeting Held In Long Beach, California, 25-27 June.

[6] Gill, P. E., Murray, W., and Wright, M. H., Practical Optimization, 1981 Academic Press,San Diego, Ca

[7] Wang, P., Development And Applications Of Production Optimization Techniques For Petroleum Fields, 2003, Phd Thesis, Palo Alto, Cs, Usa: Stanford University.

[8] Wang, P. and Litvak, M., Gas lift optimization for long-term reservoir simulations, 2004, SPE paper 90506 presented at the SPE annual technical Conference And Exhibition In Houston, Texas, USA, 26-29 September.

[9] Ilozobhie, A.J and Egu, D.I , Correlative Modelling Techniques to reducing uncertainties in a complex marginal field in the Niger Delta. Global Journal of Pure and Applied Sciences 2018,Vol 10 (24), 203-213.

[10] Obi, D.A, Ilozobhie, A.J, Lebo, S.E. and Zoogbara.E, Modelling Magnetic Basement in Relationship to Hydrocarbon Habitats in the Central Niger Delta, Nigeria. Journal of Geography, Environment and Earth Science International 2017, Vol.10(4), 1-13. 